Article

\title{
Antiproliferative Effects of New Dimeric Ellagitannin from Cornus alba in Prostate Cancer Cells Including Apoptosis-Related S-Phase Arrest
}

\author{
Kwan Hee Park ${ }^{\dagger}$, Jun Yin ${ }^{\dagger}$, Ki Hoon Yoon, Yoon Jeong Hwang and Min Won Lee * \\ Laboratory of Pharmacognosy and Natural Product based Medicine, College of Pharmacy, \\ Chung-Ang University, Seoul 156-756, Korea; kwany1982@naver.com (K.H.P.); yinjun89@naver.com (J.Y.); \\ ykhj33@naver.com (K.H.Y.); g_intention@naver.com (Y.J.H.) \\ * Correspondence: mwlee@cau.ac.kr; Tel.: +82-2-820-5602; Fax: +82-2-816-7338 \\ + These authors contributed equally to this work. \\ Academic Editor: Derek J. McPhee \\ Received: 5 January 2016; Accepted: 18 January 2016; Published: 23 January 2016
}

\begin{abstract}
Activity-guided isolation of $80 \%$ acetone extract of Cornus alba, which is traditionally used as an anti-inflammatory, hemostatic and diuretic in Korea, yielded one novel compound, tentatively designated cornusiin $\mathrm{H}$ (13), together with 12 known compounds. The known compounds included four flavonoids (catechin (1), quercetin-3-O- $\beta$-D-glucuronide (2), quercetin-3-O- $\beta$-D-glucopyranoside (3), kaempferol-3-O- $\beta$-D-glucopyranoside (4)) and eight hydrolysable tannins (gallic acid (5), 2,6-di$O$-galloyl-hamamelofuranoside (6), 2-galloyl-4-caffeoyl-L-threonic acid (7) 2,3-di-O-galloyl-4-caffeoyl-Lthreonic acid (8), 1,2,3,4,6-penta-O-galloyl- $\beta$-D-glucopyranoside (9), cornusiin B (10), cornusiin A (11) and camptothin B (12)). All compounds exhibited potent 1,1-diphenyl-2-picrylhydrazyl (DPPH)-free radical scavenging activity. Especially, the radical scavenging activities of $\mathbf{6}$ and $\mathbf{9 - 1 3}$ were higher than that of vitamin C. Compounds 9, 11, 12 and 13 inhibited the production of nitric oxide (NO) in lipopolysaccharide-stimulated RAW264.7 cells to the same degree as $N^{\mathrm{G}}$-Monomethyl-L-arginine (L-NMMA). When the antiproliferative effects of the isolated compounds were assessed in prostate cancer cells, the dimeric ellagitannins (11-13) selectively inhibited LNCaP hormone-dependent prostate cancer cells. Flow cytometry analysis indicated that the dimeric ellagitannins induced apoptosis and S-phase arrest. These results suggest that dimeric ellagitannins from Cornus alba can be developed as functional materials or herbal medicines for prostate tumors such as benign prostate hyperplasia and early-stage prostate cancer.
\end{abstract}

Keywords: Cornus alba; hydrolysable tannins; ellagitannins; antioxidant; anti-inflammatory; anti-proliferation; prostate cancer

\section{Introduction}

Prostate tumors can be categorized as benign prostate hyperplasia (BPH), which is an overgrowth of the prostate caused by extensive androgen-dependent tissue remodeling [1], and prostate cancer (PCa), which is a malignant tumor caused by oncogenic mutations, aberrant signaling or inflammatory conditions [2]. The proliferation of prostate tissue which could make urination difficult is an important problem for $\mathrm{BPH}$ [3]. The $\alpha_{1}$-Adrenergic agonists and $5 \alpha$-reductase inhibitors are typically used to treat $\mathrm{BPH}$, with the goals of improving urination and decreasing prostate growth. However, long-term issues with these medications include adverse effects, such as low blood pressure and sexual dysfunction. Hormonal therapy is used for early-stage prostate cancer. Frequently, the cancer becomes hormone-refractory. Being a typical chronic disease in middle-aged and old men, prostate tumors are likely to increase with age. BPH has been described in $62 \%$ of European middle-aged men [4]. PCa, 
the most common cancer in Western men, occurred mostly between 54 and 75 years of age [2]. The incidence of prostate tumors is rapidly increasing in Korea. A recent Korean survey reported that the prevalence of $\mathrm{BPH}$ was about $40 \%$ in men over 65 years of age [5], with the incidence of PCa increasing by an average of $12.1 \%$ annually over the past decade, ranking as the fifth most prevalent cancer in men [6]. Also, on the worldwide scale, PCa, as second in the estimated new cases and fifth in the estimated deaths in males, is one of the most prevalent cancers [7].

Plant extracts have been widely used as an alternative treatment of prostate tumors. Serenoa repens (Saw palmetto), Hypoxis rooperi (South African star grass), Urtica dioica (Stinging nettle), Curcubita pepo (Pumpkin seed oil), Secale cereale (Rye pollen), Pygeum africanum (African plum), alone and in various combinations, are commercially available for the management of BPH and lower urinary tract symptoms (LUTS) [8]. Recently, a Chinese herbal mixture designated prostate cancer-spes (PC-SPES) which is a mixture of eight different herbs, including Chrysanthemum morifolium, Ganoderma lucidum, Glycyrrhiza glabra, Isatis indigotica, Panax pseudoginseng, Rabdosia rubescens, Scutellaria baicalensis and Serona repens, became commercially available for the treatment of PCa [9]. Phytosterol ( $\beta$-sitosterol and lupeol) and phytoestrogen (genistein) are major compounds obtained from plant extracts that reportedly inhibit $5 \alpha$-reductase and synthesis of prostagladin, impose androgen and $\alpha_{1}$ blockades, and lessen inflammation.

The Cornus species of plants is also used as an East Asian folk remedy for urinary health. C. officinalis hips are a renowned natural tonic in aging men [10], and the stems of C. walteri are used as a diuretic $[11,12]$. Various phytochemicals including lignans, iridoids, terpenoids, flavonoids and tannins have been more recently isolated from these species [13-15], and Cornus extracts reportedly possess antioxidative, anti-inflammatory and anti-cancer biological activities [16]. Cornus alba (CA), also known as red-barked or Siberian dogwood, is native to Siberia, northern China and Korea [16]. The stems and leaves of CA have been used as antiphlogistic, hemostatic and diuretic treatments in Korea. [17] This ethnopharmacologic usage comes despite limited knowledge of chemistry and biological activity of this plant.

The present study was undertaken to provide clarity on its phytochemicals and biological activities. We tried to isolate active constituents and evaluated their biological activities with the goal of developing natural prostate tumor medications.

\section{Results and Discussion}

\subsection{Structural Identification and Elucidation}

Twelve known compounds were identified as catechin (1) [18], quercetin-3-O- $\beta$-D-glucuronide (2) [19], quercetin-3-O- $\beta$-D-glucopyranoside (3) [19], kaempferol-3-O- $\beta$-D-glucopyranoside (4) [20], gallic acid (5) [18], 2,6-di-O-galloyl-hamamelofuranoside (6) [21], 2-galloyl-4-caffeoyl-L-threonic acid (7) [22], 2,3-di-O-galloyl-4-caffeoyl-L-threonic acid (8) [22], 1,2,3,4,6-penta-O-galloyl- $\beta$-D-glucopyranoside (9) [23], cornusiin B (10) [24], cornusiin A (11) [25] and camptothin B (12) [24,25]. The spectroscopic data of compounds 1-12 were carefully compared with values reported in the literature (Figure 1).

Compound 13 was obtained as an amorphous brown powder. It was detected as a dark blue spot by spraying with $\mathrm{FeCl}_{3}$ solution, and as a yellow spot by spraying with $\mathrm{H}_{2} \mathrm{SO}_{4}$ solution, followed by heating on TLC. The molecular formula was $\mathrm{C}_{75} \mathrm{H}_{56} \mathrm{O}_{48}$ as indicated by HR-FAB-MS data $(\mathrm{m} / z$ $1723.1865[\mathrm{M}-\mathrm{H}]^{-}$calculated for $\left.\mathrm{C}_{75} \mathrm{H}_{55} \mathrm{O}_{48}, 1723.1863\right)$. On ${ }^{1} \mathrm{H}-\mathrm{NMR}$, all signals were duplicated, and one pair of downfield-shifted anomeric proton signals were observed at $\delta 6.18,6.18(1.7 \mathrm{H}$ in total, each $\mathrm{d}, J=8.4 \mathrm{~Hz}, \mathrm{H}-1_{\mathrm{R}}$ of each two forms). (Figure S3) These findings suggested that compound 13 should exist as an equilibrium mixture of two tautomers $\left(\alpha_{L}-\beta_{R}: \beta_{L}-\beta_{R}=1: 0.7\right)$ with an acylated anomeric center of the glucose core. Careful analysis of the ${ }^{1} \mathrm{H}-\mathrm{NMR}$ spectrum revealed six galloyl groups and one valoneoyl (val) group $(\delta 7.00,7.00,7.01,7.03,7.06,7.07,7.10,7.11,7.12,7.16$ and 7.17 (each s, $5 \times$ galloyl $\mathrm{H}-2$ and 6; val $\mathrm{H}_{\mathrm{C}}$ ), 6.93 and 6.86 (each s, galloyl $\mathrm{H}-2$ and $\mathrm{H}-6$ ), 6.69 and 6.68 (each s, val $\mathrm{H}_{\mathrm{A}}$ ) and 6.19 and 6.19 (each $\mathrm{s}$, val $\left.\mathrm{H}_{\mathrm{B}}\right)$ ) in the aromatic region, together with two glucose cores with 
a ${ }^{4} C_{1}$ conformation ( $\delta 3.80-6.23$ (large coupling constants in all sugar protons)) in the sugar region. (Figures S2 and S3)

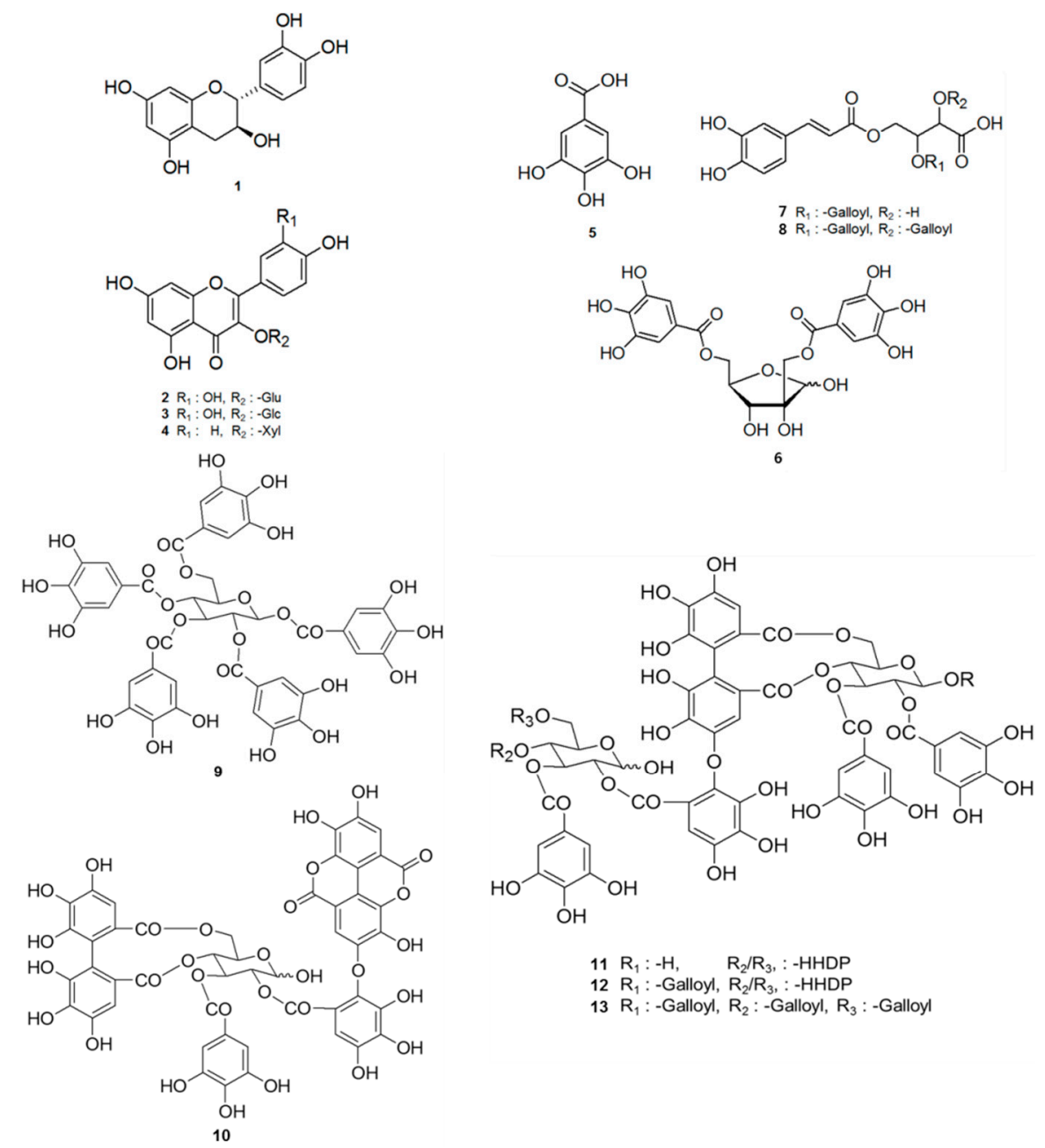

Figure 1. The structures of compounds 1-13 isolated from CA.

The positive cotton effect at the short wavelength region $\left([\theta]_{224} 8.81\right)$ in the $\mathrm{CD}$ spectrum indicated that the absolute configuration of the valoneoyl group was $S$ [26]. The downfield-shifted $\mathrm{H}-4_{\mathrm{R}}$ $\left(\delta_{\mathrm{H}} 5.11,5.12\right)$ as well as the separately observed $\mathrm{H}-6 \mathrm{a}_{\mathrm{R}}\left(\delta_{\mathrm{H}} 5.27-5.32\right)$ and $\mathrm{H}-6 \mathrm{~b}\left(\delta_{\mathrm{H}} 3.76-3.96\right)$, which were correlated with acylated anomeric $\mathrm{H}-1_{\mathrm{R}}\left(\delta_{\mathrm{H}} 6.18,6.18\right)$ in TOCSY, suggested that the valoneoyl group should be connected at $\mathrm{OH}-4 / \mathrm{OH}-6$ of the right glucose core [27]. (Figure S4) In the left glucose core, the downfield-shifted $\mathrm{H}-4_{\mathrm{L}}\left(\delta_{\mathrm{H}} 5.50,5.57\right)$ as well as the adjoined $\mathrm{H}-6 \mathrm{a}_{\mathrm{L}}\left(\delta_{\mathrm{H}} 4.47,4.51\right)$ and $\mathrm{H}-6 \mathrm{~b}_{\mathrm{L}}$ $\left(\delta_{\mathrm{H}} 4.23,4.30\right)$, which correlated with the non-acylated $\mathrm{H}-1_{\mathrm{L}}\left(\delta_{\mathrm{H}} 4.74,5.42\right)$ in TOCSY, (Figure S4) and no observation of any characteristic chemical shifts of the HHDP group at $\delta 6.40-6.60$ indicated that the two galloyl groups should connect with the OH-4 and OH- 6 of the left glucose core, respectively. (Figure S3) The upfield-shifted $\mathrm{H}-1$ of the $\beta$-anomer $\left(\delta 4.74\left(0.7 \mathrm{H}, J=7.8 \mathrm{~Hz}, \mathrm{H}-1_{\mathrm{L}}\right.\right.$ of $\beta-\beta$ form) compared with the $\alpha$-anomer in the left-side glucose core $\left(\delta 5.42\left(1 \mathrm{H}, \mathrm{d}, J=3.0 \mathrm{~Hz}, \mathrm{H}-1_{\mathrm{L}}\right.\right.$ of $\alpha-\beta$ form)) indicated that the valoneoyl group at $\mathrm{OH}-2$ of the left-side glucose core induced an anisotropic shielding effect in $\mathrm{H}-1_{\mathrm{L}}$. (Figure S1) In addition, the downfield-shifted $\mathrm{Val}_{\mathrm{A}}$ at $\delta_{\mathrm{H}} 6.68$ and 6.69 , due to absence of the shielding effect by the galloyl group at $\mathrm{OH}-3$ in the right glucose core, indicated that the left glucose core is connected at the bottom of the valoneoyl group. The ellagitannin composed with an unacylated anomeric center and substituted by two galloyl groups at $\mathrm{OH}-4$ and $\mathrm{OH}-6$ in the left glucose core was tentatively designated cornusiin $\mathrm{H}$. 


\subsection{1,1-Diphenyl-2-picrylhydrazyl (DPPH) Radical Scavenging Activity}

Reducing oxidative stress is related to the anti-cancer and anti-inflammatory effect. [28] To assess the antioxidative activity of the compounds isolated from CA, DPPH radical scavenging activity was investigated. All compounds showed radical scavenging activity in a dose-dependent manner (data not shown). Especially compounds $\mathbf{6}$ and 9-13, which are hydrolysable tannins, possessed more potent DPPH free radical scavenging activities than the vitamin $C$ positive control, while the scavenging activities of simple gallic acids (5) and galloyl caffeoyl threonic acids $(7,8)$ were moderate (Table 1$)$. The hydrolysable tannins (6 and 9-13) had more than two galloyl groups known to eliminate free radicals, and their efficiency depended on the number of galloyl groups $(\mathbf{6}<\mathbf{9}<\mathbf{1 0}, \mathbf{1 1}<\mathbf{1 2}, 13)$. Flavonols are well-known antioxidative compounds. Especially, the hydroxyl group at C-5, the ketone at C-4 and B-ring phenolic hydroxyl groups are crucial as electron acceptors. In this case, the radical scavenging activities of compounds 2 and 3, which have a $3^{\prime}, 4^{\prime}$-dihydroxylphenyl B-ring, were more potent than compound 4, which possesses a $4^{\prime}$-hydroxylphenyl B-ring.

Table 1. $\mathrm{IC}_{50}$ values of compounds $\mathbf{1 - 1 3}$ against scavenging DPPH radicals or inhibition of NO production on LPS-stimulated RAW264.7 cells.

\begin{tabular}{ccc}
\hline \multirow{2}{*}{ Samples } & \multicolumn{2}{c}{$\mathrm{IC}_{\mathbf{5 0}}(\mu \mathbf{M})^{\mathbf{a}}$} \\
\cline { 2 - 3 } & DPPH Radical Scavenging Activity & NO Production Inhibitory Activity \\
\hline $\mathbf{1}$ & $31.17 \pm 0.31$ & $100<$ \\
$\mathbf{2}$ & $23.64 \pm 1.26$ & $100<$ \\
$\mathbf{3}$ & $24.08 \pm 0.90$ & $100<$ \\
$\mathbf{4}$ & $66.45 \pm 5.79$ & $100<$ \\
$\mathbf{5}$ & $31.71 \pm 1.42$ & $100<$ \\
$\mathbf{6}$ & $9.47 \pm 0.42$ & $100<$ \\
$\mathbf{7}$ & $28.39 \pm 1.68$ & $100<$ \\
$\mathbf{8}$ & $20.98 \pm 1.10$ & $100<$ \\
$\mathbf{9}$ & $8.45 \pm 1.99$ & $28.59 \pm 0.82$ \\
$\mathbf{1 0}$ & $6.72 \pm 0.16$ & $98.74 \pm 8.91$ \\
$\mathbf{1 1}$ & $6.01 \pm 0.16$ & $20.99 \pm 0.14$ \\
$\mathbf{1 2}$ & $5.40 \pm 0.16$ & $20.93 \pm 0.15$ \\
$\mathbf{1 3}$ & $5.52 \pm 0.28$ & $21.26 \pm 0.38$ \\
Vit.C $^{\mathrm{b}}$ & $13.30 \pm 0.31$ & - \\
L-NMMA $^{\mathrm{b}}$ & - & $17.10 \pm 0.25$ \\
\hline
\end{tabular}

${ }^{\mathrm{a}}$ Values are presented as the mean $\pm \mathrm{SD}(n=3) ;{ }^{\mathrm{b}}$ Positive controls. Vit.C: L-ascorbic acid; L-NMMA: $N^{\mathrm{G}}$-monomethyl-L-arginine.

\subsection{Inhibition of Nitric Oxide (NO) Production}

It is reported that there is a strong correlation between the inflammation and the pre-cancerous lesion, [29] so the anti-inflammatory effect could also partly reflect the anti-cancer effect. To evaluate the anti-inflammatory activities of the compounds isolated from CA, their inhibition of NO production in LPS-stimulated RAW264.7 cells was investigated as described previously [30]. While the flavonoids (1-4) and mono- or di-galloyl substituted tannins (5-8) had no effect, the hydrolysable tannins (9-13) dramatically inhibited NO production to almost the same degree as $N^{\mathrm{G}}$-monomethyl-L-arginine (L-NMMA), except for 10, which has a substituted lactonized valoneoyl group (Table 1). These findings indicated that the lactonized valoneoyl moiety may not be helpful for the intracellular effects of hydrolysable tannins.

\subsection{Antiproliferative Activity on Prostate Cancer Cells}

Besides the indirect anti-cancer effect, which includes anti-oxidative and anti-inflammatory activities, the antiproliferative activity on cancer cells could more directly affect the anti-cancer activity. To evaluate the antitumor effects of the compounds isolated from CA, the antiproliferative effect 
of each compound was determined using a 3-(4,5-Dimethylthiazol-2-yl)-2,5-Diphenyltetrazolium Bromide (MTT) assay on androgen-dependent LNCaP and androgen-insensitive DU145 cell lines. The antiproliferative activity of $50 \mu \mathrm{M}$ of each compound was screened in LNCaP and DU145 cells and RWPE-1 normal prostate epithelial cells together with other tannin-related compounds previously isolated from other plant sources. The compounds were divided into five groups as follows: (1) condensed tannins: 1; (2) flavononol glycosides: 2-4; (3) gallotannins: 5-9; (4) monomeric ellagitannins: 10; and (5) dimeric ellagitannins: 11-13. All dimeric ellagitannins showed selective antiproliferative effects on LNCaP cells. These compounds decreased the cell viability of LNCaP four to five times more than that of RWPE-1. This finding suggested that the HHDP group on ellagitannins might increase the antiproliferative effects of androgen-dependent LNCaP. Interestingly, compound 10, which possesses a lactonized valoneoyl group at $\mathrm{OH}-2$, was decreased. Thus, the rigid valoneoyl group at $\mathrm{OH}-2$ and the flexible galloyl group at $\mathrm{OH}-2$ and $\mathrm{OH}-3$ may be essential for selective antiproliferation. The antiproliferative effects of compounds 9-13 were assessed at various concentrations using LNCaP and DU145 cells. Especially, dimeric ellagitannins (11-13) inhibited the proliferation of LNCaP cells seven times more potently than DU145 cells, which means dimeric ellagitannins could inhibit the proliferation of hormone-dependent PCa cells more powerfully than hormone-insensitive PCa cells (Table 2), and decreased the cell viability of LNCaP cells more effectively than monomeric ellagitannins did (Figure 2).

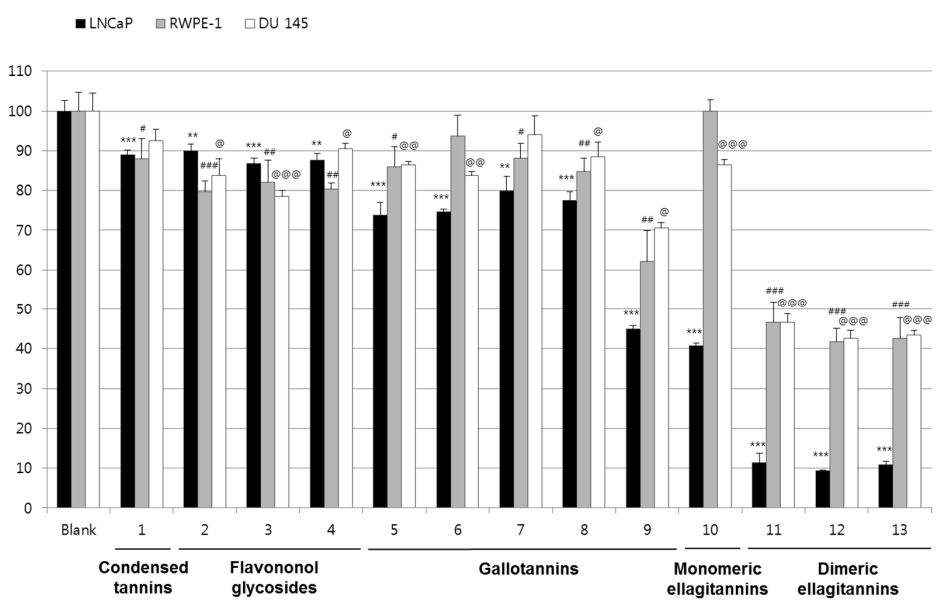

Figure 2. The antiproliferative effects of 1-13 from C. alba. Each compound was treated at the concentration of $50 \mu \mathrm{M}$ into androgen-dependent prostate tumor LNCaP, androgen-independent prostate tumor DU145 and normal prostate epithelial RWPE-1 cells. The results were expressed as mean \pm S.D. of triplicated experiments. ${ }^{* *}: p<0.01,{ }^{* * *}: p<0.001$, compare with LNCaP Blank group; \#: $p<0.05$,\#\#: $p<0.01$,\#\#: $p<0.001$, compare with RWPE-1 Blank group; @: $p<0.05$, @ : $p<0.01$, @@@: $p<0.001$, compare with LNCaP Blank group.

Table 2. $\mathrm{IC}_{50}$ values of $\mathbf{9 - 1 3}$ against the cell viability of LNCaP and DU145.

\begin{tabular}{ccc}
\hline \multirow{2}{*}{ Samples } & \multicolumn{2}{c}{ IC $_{\mathbf{5 0}}(\mu \mathbf{M})^{\mathbf{a}}$} \\
\cline { 2 - 3 } & LNCaP & DU145 \\
\hline $\mathbf{9}$ & $50<$ & $100<$ \\
$\mathbf{1 0}$ & $50<$ & $100<$ \\
$\mathbf{1 1}$ & $6.31 \pm 0.23$ & $48.32 \pm 5.12$ \\
$\mathbf{1 2}$ & $6.03 \pm 0.16$ & $41.48 \pm 2.42$ \\
$\mathbf{1 3}$ & $5.97 \pm 0.15$ & $44.06 \pm 1.43$ \\
\hline EGCG $^{\mathrm{b}}$ & $50<$ & $100<$ \\
\hline
\end{tabular}

${ }^{\mathrm{a}}$ Values are presented as the mean $\pm \mathrm{SD}(n=3) ;{ }^{\mathrm{b}}$ Positive controls. 


\subsection{Induction of Cell Cycle Arrest and Apoptosis}

The apoptosis effect of PCa is helpful to assay the anti-cancer effect. To observe cell cycle distribution and apoptosis by the ellagitannins (9-13) obtained from CA, flow cytometry analysis was performed. Compounds 11-13 which effectively are dimeric ellagitannins induced apoptosis within $48 \mathrm{~h}$, and the potency of dimeric ellagitannins was two to three times better than that of monomeric ellagitannins (Figure 3). Compound $\mathbf{1 1}$ elevated the subG1 phase of both LNCaP and DU145 cells in a dose-dependent manner, and the potency for LNCaP cells was 10 times greater than that of DU145 cells (Figure 3). Compound 11 applied at a low concentration also increased the S-phase, while the cells in G0/G1 and G2/M were decreased (Figure 3). These findings suggested that dimeric ellagitannins may induce S-phase arrest and apoptosis.

A $\operatorname{LNCaP}(5 \mu \mathrm{M})$

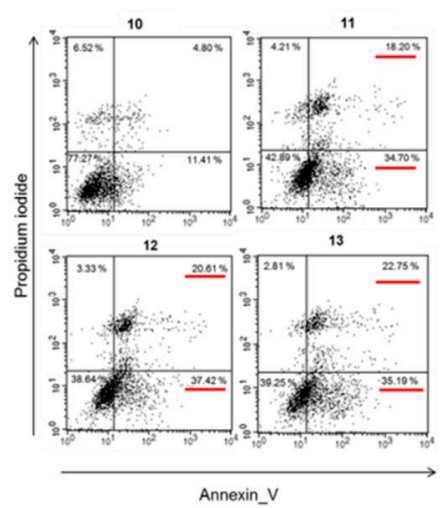

B

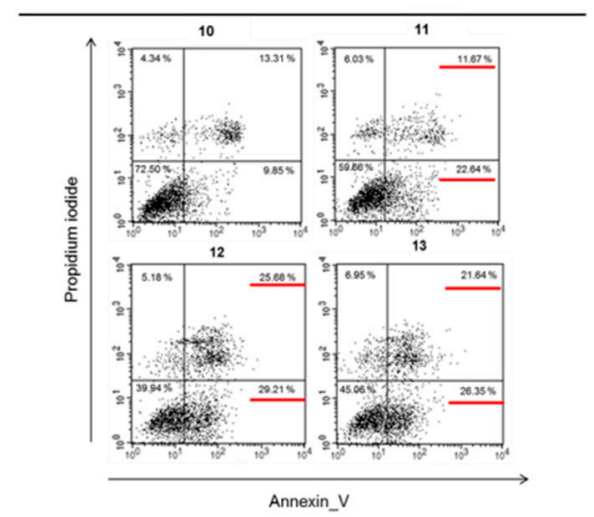

C

$\operatorname{LNCaP}(5 \mu \mathrm{M})$

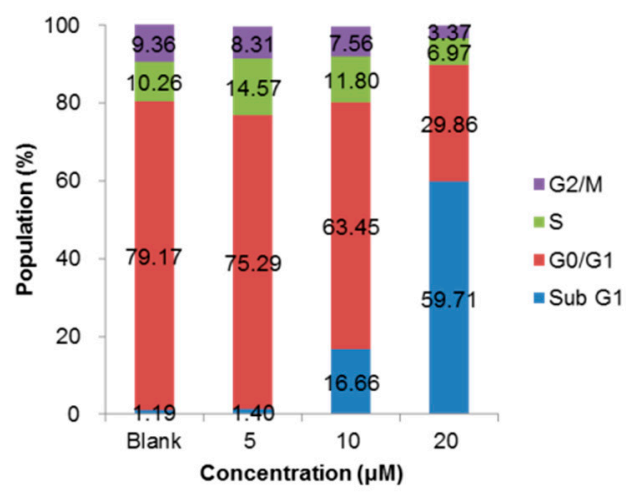

D

DU145 (50 $\mu \mathrm{M})$

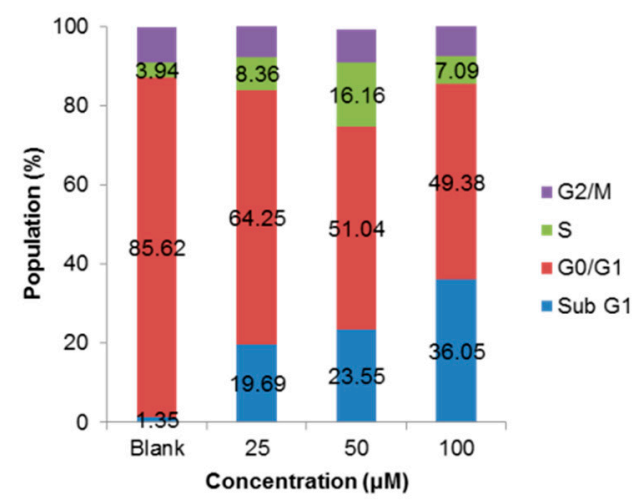

Figure 3. Induction of apoptosis (A,B) and cell cycle arrest (C,D) by dimeric ellagitannins (11-13) from C. alba. The apoptosis induction and cell cycle distribution were analyzed on flow cytometry. Concentrations of 5 or $50 \mu \mathrm{M}$ of each compound were used to treat LNCaP and DU145 cells for $48 \mathrm{~h}$, respectively. In A and B, the percentages of cells in each quadrant are indicated as follows-lower left: normal, lower right: early apoptosis, upper right: late apoptosis, upper left: necrosis.

\section{Materials \& Methods}

\subsection{Plant Material}

CA $(5.7 \mathrm{~kg}$ ) was collected at the Korea National Arboretum (Pocheon, Korea) in September 2011. The identification of the material was certificated by Mr. Kim Sung Sik, Curator in the Department of Horticulture and Landscape Design. A voucher specimen (CA2011) was deposited at the herbarium of the College of Pharmacy, Chung-Ang University (Seoul, Korea). 


\subsection{General Procedures}

Column chromatography was performed using a Sephadex LH-20 column (10-25 $\mu \mathrm{m}$; GE

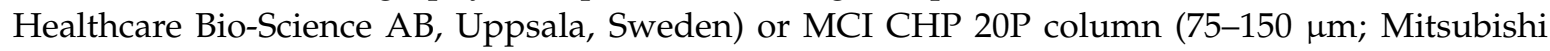
Chemical, Tokyo, Japan). Daisogel (40-60 $\mu \mathrm{m}$; Daiso, Osaka, Japan) and Toyopearl HW-40F (30-60 $\mu \mathrm{m}$; Tosoh Corp., Tokyo, Japan) were used in the stationary phase in a middle-pressure liquid chromatography (MPLC) system (Gilson, Seoul, Korea). For monitoring of each fraction, thin layer chromatography (TLC) was carried out using pre-coated silica gel $60 \mathrm{~F}_{254}$ plates (Merck, Darmstadt, Germany) that were developed with chloroform, methanol and water (6:4:1 volume ratio), or benzene, ethylformate and formic acid (1:7:1 or 1:7:2 volume ratio). The spots were detected using ultraviolet radiation $(254 \mathrm{~nm})$ and by spraying with a $\mathrm{FeCl}_{3}$ solution and $10 \% \mathrm{H}_{2} \mathrm{SO}_{4}$ followed by heating. Structural identification was by nuclear magnetic resonance (NMR; Varian, Palo Alto, CA, USA), high resolution fast atom bombardment mass spectrum (HRFAB-MS; JEOL, Tokyo, Japan) and circular dichroism (CD; Jasco, Tokyo, Japan).

\subsection{Extraction and Isolation}

Several extractions of CA ( $5.7 \mathrm{~kg}$ ) using $80 \%$ acetone at room temperature followed by removal of the acetone under vacuum yielded $463 \mathrm{~g}$ of extract. The extract was dissolved in water and filtered through Celite 545 (Duksan Pure Chemical, Ansan, Korea). Then $356 \mathrm{~g}$ of water-soluble fraction was obtained together with $89 \mathrm{~g}$ of water-insoluble residue; $243 \mathrm{~g}$ of the water-soluble fraction applied to a Sephadex LH-20 column $(15 \times 100 \mathrm{~cm})$ equilibrated with water. The column was eluted with a water-methanol gradient system and washed in $60 \%$ acetone, which yielded 14 fractions.

Fraction $6(2.5 \mathrm{~g})$ was applied to Daisogel $(3 \times 50 \mathrm{~cm}$, here and hereafter) with the water-methanol gradient in the MPLC system $(5 \mathrm{~mL} / \mathrm{min}, 280 \mathrm{~nm}$, here and hereafter) to yield quercetin-3-O- $\beta$-Dglucuronide $(2,143 \mathrm{mg})$. Fraction $7(2.7 \mathrm{~g})$ was applied to Daisogel with the water-methanol gradient in the MPLC system (5 mL/min, $280 \mathrm{~nm}$, here and hereafter) to yield gallic acid $(5,121 \mathrm{mg}$ ). Fraction $8(12.8 \mathrm{~g})$ was applied to a MCI CHP20P column $(5 \times 60 \mathrm{~cm}$, here and hereafter $)$ with the water-methanol gradient to obtain catechin $(1,27 \mathrm{mg})$, quercetin-3-O- $\beta$-D-glucopyranoside $(3,157 \mathrm{mg})$, kaempferol-3-O- $\beta$-D-glucopyranoside $(4,24 \mathrm{mg})$, hamamelitannin $(6,1.2 \mathrm{~g})$ and 2-galloyl-4-caffeoyl-Lthreonic acid $(7,32 \mathrm{mg})$. Fraction $11(3.4 \mathrm{~g})$ was repeatedly applied to a Daisogel column using the water-methanol gradient in the MPLC system to obtain 2,3-di-galloyl-4-caffeoyl-L-threonic acid $(8,27 \mathrm{mg})$. Fraction $13(\mathbf{3 1}, 6 \mathrm{~g})$ was applied to a MCI CHP20P column with the water-methanol gradient to obtain five sub-fractions. Fraction 13-2 was applied to a Daisogel column with the water to $20 \%$ methanol gradient in the MPLC system and was further separated by column chromatography on a Sephadex LH-20 column with a water-methanol-60\% acetone gradient system to obtain cornusiin B (10, $140 \mathrm{mg})$ and cornusiin A (11, $1.2 \mathrm{~g})$. Fraction 13-3 was applied to a Sephadex LH-20 column $(2.5 \times 50 \mathrm{~cm}$, here and hereafter $)$ with the water-methanol- $60 \%$ acetone gradient system and further separated by column chromatography on a MCI CHP20P column with water-methanol gradient system resulted to three additional sub-fractions. Fr 13-3-1 was chromatographed by Toyopearl HW-40 $(2.5 \times 50 \mathrm{~cm})$ with 70\% methanol-70\% acetone $(10: 0 \rightarrow 7: 3)$, and then yielded camptothin B (12, $815 \mathrm{mg})$. Fr 13-3-3 was chromatographed using a Sephadex LH-20 column with a 100\% ethanol-100\% methanol gradient system to obtain the novel compound tentatively designated cornusiin $\mathrm{H}(\mathbf{1 3}, 312 \mathrm{mg})$. Fraction 13-4 was applied to Daisogel with the water-methanol gradient in a MPLC system to yield 1,2,3,4,6-penta-O-galloyl- $\beta$-D glucopyranoside $(9,27 \mathrm{mg})$. TLC was developed using chloroform, methanol and water (6:4:1 volume ratio) and each spot was detected by spraying with $10 \% \mathrm{H}_{2} \mathrm{SO}_{4}$ followed by heating and with ethanolic $\mathrm{FeCl}_{3}$. In the corresponding photograph, TLC patterns of CA $80 \%$ acetone extract and water-soluble/insoluble layer are shown in panel A and each sub-fraction obtained by column chromatography with Sephadex LH-20 from the water-soluble layer are shown in panel B. 


\section{Cornusiin $\mathrm{H}(\mathbf{1 3})$}

The product was an amorphous brown powder. Structural data are as follows:

HRFAB-MS m/z: $1723.1865[\mathrm{M}-\mathrm{H}]^{-}$(calculated for $\mathrm{C}_{75} \mathrm{H}_{55} \mathrm{O}_{48}, 1723,1863$ )

$\mathrm{CD}(\mathrm{MeOH}):[\theta]_{224} 8.81,[\theta]_{258}-0.89,[\theta]_{278} 2.09$

${ }^{1} \mathrm{H}-\mathrm{NMR}\left(600 \mathrm{MHz}\right.$, Acetone- $\left.d_{6}+\mathrm{D}_{2} \mathrm{O}\right): \delta 3.88-3.92\left(1.7 \mathrm{H}\right.$ in total, each br $\mathrm{d}, J=13.2, \mathrm{H}-6 \mathrm{~b}_{\mathrm{R}}$ of each two form), $4.17\left(0.7 \mathrm{H}\right.$, ddd, $J=2.4,4.2,10.2 \mathrm{~Hz}, \mathrm{H}-5_{\mathrm{L}}$ of $\beta-\beta$ form $), 4.23(0.7 \mathrm{H}, \mathrm{dd}, J=4.2,13.2 \mathrm{~Hz}$, $\mathrm{H}-6 \mathrm{~b}_{\mathrm{L}}$ of $\beta-\beta$ form $), 4.30\left(1 \mathrm{H}, \mathrm{dd}, J=4.2,13.2 \mathrm{~Hz}, \mathrm{H}-6 \mathrm{~b}_{\mathrm{L}}\right.$ of $\alpha-\beta$ form $), 4.47(1 \mathrm{H}, \mathrm{dd}, J=4.2,13.2 \mathrm{~Hz}$, $\mathrm{H}-6 \mathrm{a}_{\mathrm{L}}$ of $\alpha-\beta$ form $), 4.48\left(1 \mathrm{H}, \mathrm{m}, \mathrm{H}-5_{\mathrm{R}}\right.$ of $\alpha-\beta$ form $), 4.51\left(0.7 \mathrm{H}, \mathrm{dd}, J=4.2,13.2 \mathrm{~Hz}, \mathrm{H}-6 \mathrm{a}_{\mathrm{L}}\right.$ of $\beta-\beta$ form $)$, $4.53\left(0.7 \mathrm{H}, \mathrm{m}, \mathrm{H}-5_{\mathrm{R}}\right.$ of $\beta-\beta$ form $), 4.17\left(1 \mathrm{H}, \mathrm{ddd}, J=2.4,4.2,10.2 \mathrm{~Hz}, \mathrm{H}-5_{\mathrm{L}}\right.$ of $\alpha-\beta$ form $), 4.74(0.7 \mathrm{H}$, $J=7.8 \mathrm{~Hz}, \mathrm{H}-1_{\mathrm{L}}$ of $\beta-\beta$ form $), 5.11,5.12\left(1.7 \mathrm{H}\right.$ in total, each $\mathrm{t}, J=9.6 \mathrm{~Hz}, \mathrm{H}-4_{\mathrm{R}}$, of each two form), 5.13 $\left(1 \mathrm{H}, \mathrm{dd}, J=3.0,9.6 \mathrm{~Hz}, \mathrm{H}-2_{\mathrm{L}}\right.$ of $\alpha-\beta$ form $), 5.18\left(0.7 \mathrm{H}, \mathrm{dd}, J=7.8,9.6 \mathrm{~Hz}, \mathrm{H}-2_{\mathrm{L}}\right.$ of $\beta-\beta$ form $), 5.27-5.32$ (1.7H in total, each dd, $J=6.6,13.2, \mathrm{H}-6 \mathrm{a}_{\mathrm{R}}$ of each two form), $5.42\left(1 \mathrm{H}, \mathrm{d}, J=3.0 \mathrm{~Hz}, \mathrm{H}-1_{\mathrm{L}}\right.$ of $\alpha-\beta$ form), $5.50\left(0.7 \mathrm{H}, \mathrm{t}, J=9.6 \mathrm{~Hz}, \mathrm{H}-4_{\mathrm{L}}\right.$ of $\beta-\beta$ form $), 5.55\left(0.7 \mathrm{H}, \mathrm{dd}, J=7.8,9.6 \mathrm{~Hz}, \mathrm{H}-2_{\mathrm{R}}\right.$ of $\alpha-\beta$ form $), 5.57(1.0 \mathrm{H}$, $\mathrm{dd}, J=7.8,9.6 \mathrm{~Hz}, \mathrm{H}-2_{\mathrm{R}}$ of $\beta-\beta$ form $), 5.57\left(1 \mathrm{H}, \mathrm{t}, J=9.6 \mathrm{~Hz}, \mathrm{H}-4_{\mathrm{L}}\right.$ of $\alpha-\beta$ form $), 5.61(0.7 \mathrm{H}, \mathrm{t}, J=9.6 \mathrm{~Hz}$, $\mathrm{H}-3_{\mathrm{R}}$ of $\beta-\beta$ form $), 5.62\left(1.0 \mathrm{H}, \mathrm{t}, J=9.6 \mathrm{~Hz}, \mathrm{H}-3_{\mathrm{R}}\right.$ of $\alpha-\beta$ form $), 5.68\left(0.7 \mathrm{H}, \mathrm{t}, J=9.6 \mathrm{~Hz}, \mathrm{H}-3_{\mathrm{L}}\right.$ of $\beta-\beta$ form), $6.06\left(1 \mathrm{H}, \mathrm{t}, J=9.6 \mathrm{~Hz}, \mathrm{H}-3_{\mathrm{L}}\right.$ of $\alpha-\beta$ form $), 6.18,6.18\left(1.7 \mathrm{H}\right.$ in total, each $\mathrm{d}, J=8.4 \mathrm{~Hz}, \mathrm{H}-1_{\mathrm{R}}$ of each two forms), 6.19, 6.19 (1.7H in total, each $\mathrm{s}$, val $\mathrm{H}_{\mathrm{B}}$ of each two forms), $6.68\left(1 \mathrm{H}, \mathrm{s}, \mathrm{val} \mathrm{H}_{\mathrm{A}}\right.$ of $\alpha-\beta$ form), $6.69\left(0.7 \mathrm{H}\right.$, s, val $\mathrm{H}_{\mathrm{A}}$ of $\beta-\beta$ form $), 6.86(0.7 \mathrm{H}, \mathrm{s}$, galloyl $\mathrm{H}-2,6$ of $\beta-\beta$ form $)$ and $6.93(1 \mathrm{H}$, s, galloyl $\mathrm{H}-2$, 6 of $\alpha$ - $\beta$ form), 7.00, 7.00, 7.01, 7.03, 7.06, 7.07, 7.10, 7.11, 7.12, 7.16, 7.17 (each s, $5 \times$ galloyl H-2, 6 ; val $\mathrm{H}_{\mathrm{C}}$ of each two forms).

${ }^{13} \mathrm{C}-\mathrm{NMR}\left(150 \mathrm{MHz}\right.$, Acetone- $\left.d_{6}+\mathrm{D}_{2} \mathrm{O}\right): \delta 62.2,63.1$ (C- $6_{\mathrm{L}}$ and $\mathrm{C}-6_{\mathrm{R}}$ of each two forms), $67.5,\left(\mathrm{C}-5_{\mathrm{L}}\right.$ of $\alpha-\beta$ form ), 68.9 (C-4 $4_{L}$ of each two forms), $70.1-70.4$ (C- $4_{R}$ of each two forms; $C-3_{L}$ of $\alpha-\beta$ form) 70.9 (C-5 $5_{L}$ of $\beta-\beta$ form; $C-5_{R}$ of each two forms), 71.9-72.2 (C-2 $L_{L}$ and $C-2_{R}$ of each two forms; $C-3_{R}$ of $\alpha-\beta$ form, $C-3_{R}$ of $\beta-\beta$ form, $C-3_{L}$ of $\beta-\beta$ form), $89.9\left(C-1_{L}\right.$ of $\alpha-\beta$ form), $92.7\left(C-1_{R}\right.$ of $\alpha-\beta$ form, $C-1_{R}$ of $\beta-\beta$ form), 94.8 (C-1 $\mathrm{L}_{\mathrm{L}}$ of $\beta-\beta$ form), 104.0-104.5 (val C-3'), 107.1-107.3 (val C-3), 108.9-109.5 (gal C-2, gal C-6; val C-6" ${ }^{\prime \prime}$ ), 112.6, 113.6, 114.9, 115.3, 116.6, 116.8 (val C-1, val C-1', val C-1' ${ }^{\prime \prime}$ ), 118.6-120.4 (gal C-1), 124.7, 125.0 (val C-2, val C-2'), 133.5-136.8 (val C-5, val C-5', val-2"'), 138.1-139.0 (gal C-4), 139.0-139.7 (val C-3" ${ }^{\prime \prime}$, val C-4" $\left.{ }^{\prime \prime}\right), 142.3-142.5$ (val C-5"'), 143.7-145.3 (gal C-3, gal C-5; val C-4, val C-6, val C-6'), 145.7-146.7 (val C-4') and163.9-167.8 (gal C-7; val C-7, val C-7' val C-7'”).

\subsection{Measurement of DPPH Radical Scavenging Activity}

Antioxidant activity was determined on the basis of the scavenging activity of the stable DPPH free radical (Sigma-Aldrich, St. Louis, MO, USA). Each $20 \mu \mathrm{L}$ of sample in absolute ethanol was added to $180 \mu \mathrm{L}$ of $0.1 \mathrm{mM}$ DPPH in absolute ethanol. After mixing gently and standing for $30 \mathrm{~min}$, the optical density was measured at $540 \mathrm{~nm}$ using an ELISA reader (TECAN, Salzburg, Austria). The free radical scavenging activity was calculated as inhibition rate $(\%)=[1-($ sample O.D. $/$ control O.D. $)] \times 100 ; \mathrm{IC}_{50}$ was the concentration that could scavenge $50 \% \mathrm{DPPH}$ free radical. L-ascorbic acid was used as positive control.

\subsection{Cell Culture}

RAW 246.7, LNCaP and DU145 cells were purchased from the Korean Cell Line Bank. These cells were grown at $37^{\circ} \mathrm{C}$ in a humidified atmosphere $\left(5 \% \mathrm{CO}_{2}\right)$ in DMEM or RPMI (Sigma-Aldrich) containing 10\% fetal bovine serum (FBS) and $100 \mathrm{IU} / \mathrm{mL}$ penicillin G (Gibco BRL, Grand Island, NY, USA).

\subsection{Viability Assay}

Approximately $10^{5}$ /well of RAW264.7 or DU145 cells were seeded in wells of a 24-well plate and incubated for $4 \mathrm{~h}$ in $5 \% \mathrm{CO}_{2}$ at $37^{\circ} \mathrm{C}$. LNCaP cells were seeded at a density of $10^{4}$ cells $/$ well and 
were incubated for $24 \mathrm{~h}$. The medium was replaced with phosphate buffered saline (PBS) containing $0.5 \mathrm{mg} / \mathrm{mL}$ of 3-(4,5-dimethylthiazol-2-yl)-2,5-diphenyltetrazolium bromide (MTT), and incubated for $4 \mathrm{~h}$. The supernatant was removed and the MTT-formazan was dissolved in $200 \mu \mathrm{L}$ dimethylsulfoxide. The extent of the reduction of MTT to formazan within the cells was measured at $540 \mathrm{~nm}$ with microplate reader (TECAN, Salzburg, Austria). The cell viability was calculated as sample O.D./blank O.D. $\times 100(\%)$.

\subsection{Measurement of Inhibition of Nitric Oxide (NO) Production}

RAW 264.7 cells were cultured in wells of a 24 -well plate and incubated for $4 \mathrm{~h}$ at $37{ }^{\circ} \mathrm{C}$ in a humidified atmosphere of $5 \% \mathrm{CO}_{2}$. The cells were treated with i1 $\mu \mathrm{g} / \mathrm{mL}$ lipopolysaccharide (LPS; Sigma-Aldrich) and incubated for $24 \mathrm{~h}$. The NO content was determined by the Griess assay. Griess reagent $\left(100 \mu \mathrm{L}\right.$ of $0.1 \%$ naphthylethylenediamine and $1 \%$ sulfanilamide in $5 \% \mathrm{H}_{3} \mathrm{PO}_{4}$ solution; Sigma-Aldrich) was added to $100 \mu \mathrm{L}$ of each supernatant. NO was then measured at $540 \mathrm{~nm}$ with a microplate reader (TECAN). NO was quantified using a sodium nitrite standard curve as previously described [30]. NO inhibitory activity was calculated as [1 - (sample O.D. - blank O.D.)]/( negative control O.D. - blank O.D.) $\times 100(\%)$.

\subsection{Flow Cytometry Analysis of Cell Cycle Arrest}

The cells were harvested and washed once in PBS. The cell pellet was re-suspended in $400 \mu \mathrm{L}$ PBS containing $2 \% \mathrm{FBS}$ and fixed in $1.2 \mathrm{~mL} 70 \%$ ethanol for $24 \mathrm{~h}$ at $-20{ }^{\circ} \mathrm{C}$. Cells were washed twice in PBS and treated with $0.1 \%$ Triton X-100 and ribonuclease A $(100 \mu \mathrm{g} / \mathrm{mL})$ in PBS for $20 \mathrm{~min}$. Propidium iodide (PI; $25 \mu \mathrm{g} / \mathrm{mL}$ ) was added and flow cytometry was carried out using a BD-LSR II flow cell cytometer (BD, San Jose, CA, USA) using Cell Quest software.

\subsection{Flow Cytometry Quantification of Apoptosis}

Cells were harvested and washed once in PBS and once in annexin V binding buffer. The cells were resuspended in binding buffer and stained with annexin V-fluorescein isothiocynate (FITC) and PI for $15 \mathrm{~min}$ in the dark at $4{ }^{\circ} \mathrm{C}$. The fluorescence was analyzed by flow cytometry as described above. The percentages of necrotic cells, early and late apoptotic cells, and viable cells were compared.

\section{Conclusions}

A new dimeric ellagitannin, designated cornusiin $\mathrm{H}$ (13), was isolated from CA together with 12 known phenolic compounds. Dimeric ellagitannins (11-13) showed potent DPPH radical scavenging activity and inhibited NO production in LPS-stimulated RAW 264.7 cells. Also, they selectively inhibited proliferation of LNCaP hormone-dependent prostate tumor cells. The rigid 4,6-HHDP group and flexible 2,3-O-digalloyl were essential for the antiproliferative effects and dimerization via the valoneoyl group's increased activity. The dimeric ellagitannins efficiently induced apoptosis as well as S-phase arrest. Thus, the dimeric ellagitannins or ellagitannin-rich fraction from CA might be developed as functional material to alleviate prostate tumors (BPH or early-stage $\mathrm{PCa}$ ) through future clinical study.

Supplementary Materials: Supplementary materials can be accessed at: http://www.mdpi.com/1420-3049/ $21 / 2 / 137 / \mathrm{s} 1$.

Acknowledgments: This study was supported by the Basic Science Research Program through the National Research Foundation of Korea (NRF-2014R1A1A2056899) funded by the Ministry of Education, Science, and Technology and this research was supported by the Chung-Ang University research grant in 2013.

Author Contributions: K.H. Park and M.W. Lee, conceived and designed the experiments; J. Yin and K.H. Yoon performed the experiments; J. Yin and K.H. Yoon analyzed the data; Y.J. Hwang contributed reagents/materials/analysis tools; K.H. Park wrote the paper.

Conflicts of Interest: The authors declare no conflict of interest. 


\section{References}

1. Untergasser, G.; Madersbacher, S.; Berger, P. Benign prostatic hyperplasia: Age-related tissue-remodeling. Exp. Gerontol. 2005, 40, 121-128. [CrossRef] [PubMed]

2. Khandrika, L.; Kumar, B.; Koul, S.; Maroni, P.; Koul, H.K. Oxidative stress in prostate cancer. Cancer Lett. 2009, 282, 125-136. [CrossRef] [PubMed]

3. Pagano, E.; Laudato, M.; Griffo, M.; Capasso, R. Phytotherapy of benign prostatic hyperplasia. A mini review. Phytother. Res. 2014, 28, 949-955. [CrossRef] [PubMed]

4. Gades, N.M.; Jacobson, D.J.; Girman, C.J.; Roberts, R.O.; Lieber, M.M.; Jacobsen, S.J. Prevalence of conditions potentially associated with lower urinary tract symptoms in men. BJU Int. 2005, 95, 549-553. [CrossRef] [PubMed]

5. Park, H.K.; Park, H.; Cho, S.Y.; Bae, J.; Jeong, S.J.; Hong, S.K.; Yoon, C.Y.; Byun, S.S.; Lee, S.E.; Kim, K.W. The prevalence of benign prostatic hyperplasia in elderly men in Korea: A community-based study. Korean J. Urol. 2009, 50, 843-884. [CrossRef]

6. Lee, J.S. Cancer Facts E Figures 2014 in the Republic of Korea, 1st ed.; National Cancer Center: Gyeonggi-do, Korea; Ministry of Health \& Welfare: Seoul, Korea, 2014; pp. 8-10.

7. American Cancer Society, Global Facts and Figures. Atlanta Cancer Society, 3rd ed.; American Cancer Society: Atlanta, GA, USA, 2015; p. 2.

8. Lowe, F.C. Phytotherapy in the management of benign prostatic hyperplasia. Urology 2011, 58, 71-77. [CrossRef]

9. Yip, I.; Cudiamat, M.; Chim, D. PC-SPES for treatment of prostate cancer: Herbal medicine. Curr. Urol. Rep. 2003, 4, 253-257. [CrossRef] [PubMed]

10. Koh, K.S.; Jeon, E.S. Ferns, Fern-Allies and Seed-Bearing Plants of Korea, 1st ed.; Iljinsa publishing company: Seoul, Korea, 2003; p. 494.

11. Kim, D.K.; Kwak, J.H. A Furan Derivation from Cornus officinalis. Arch. Pham. Res. 1998, 21, 787-789. [CrossRef]

12. Kim, K.H.; Choi, S.U.; Kim, Y.C.; Lee, K.R. Tirucallane triterpenoids from Cornus walteri. J. Nat. Prod. 2011, 74, 54-59. [CrossRef] [PubMed]

13. Endo, T.; Taguchi, H. Studies on the consitituents of Comus officinalis Sieb. et Zucc. Yakugaku Zasshi 1973, 93, 30-32. [PubMed]

14. Lee, D.Y.; Lyu, H.N.; Kwak, H.Y. Isolation of flavonoids from the fruits of Cornus kousa Burg. J. Appl. Biol. Chem. 2007, 50, 144-147.

15. Lee, D.Y.; Song, M.C.; Yoo, K.H.; Bang, M.H.; Chung, I.S.; Kim, S.H.; Kim, D.K.; Kwon, B.M.; Jeong, T.S.; Park, M.H.; et al. Lignans from the fruits of Cornus kousa Burg. and their cytotoxic effects on human cancer cell lines. Arch Pharm Res. 2007, 30, 402-407. [CrossRef] [PubMed]

16. Bjorøy, Ø.; Fossen, T.; Andersen, Ø.M. Anthocyanin 3-galactosides from Cornus alba "Sibirica" with glucosidation of the B-ring. Phytochemistry 2007, 68, 640-645. [CrossRef] [PubMed]

17. Cornus alba in Korean. Available online: http:/ / terms.naver.com/entry.nhn?docId=1216039\&cid=40942\& categoryId=32711 (accessed on 28 December 2015).

18. Lu, Y.; Yeap Foo, L. The polyphenol constituents of grape pomace. Food Chem. 1999, 65, 1-8. [CrossRef]

19. Lodi, F.; Jimenez, R.; Moreno, L.; Kroon, P.A.; Needs, P.W.; Hughes, D.A.; Santos-Buelga, C.; Gonzalez-Paramas, A.; Cogolludo, A.; Lopez-Sepulveda, R.; et al. Glucuronidated and sulfated metabolites of the flavonoid quercetin prevent endothelial dysfunction but lack direct vasorelaxant effects in rat aorta. Atherosclerosis 2009, 204, 34-39. [CrossRef] [PubMed]

20. Yasukawa, K.; Takido, M. A flavonol glycoside from Lysimachia mauritiana. Phytochemistry 1987, 26, 1224-1226. [CrossRef]

21. Nonaka, G.; Ishimaru, K.; Tanaka, T.; Nishioka, I. Tannins and related compounds. XVII. Galloylhamameloses from Castanea crenata L. and Sanguisorba officinalis L. Chem. Pharm. Bull. 1984, 32, 483-489. [CrossRef]

22. Lee, D.; Kang, S.-J.; Lee, S.-H.; Ro, J.; Lee, K.; Kinghorn, A.D. Phenolic compounds from the leaves of Cornus controversa. Phytochemistry 2000, 53, 405-407. [CrossRef]

23. Cho, J.Y.; Sohn, M.J.; Lee, J.; Kim, W.G. Isolation and identification of pentagalloylglucose with broad-spectrum antibacterial activity from Rhus trichocarpa Miquel. Food Chem. 2010, 123, 501-506. [CrossRef] 
24. Hatano, T.; Ogawa, N.; Kira, R.; Yasuhara, T.; Okuda, T. Tannins of Cornaceous Plant. I. Cornusiins A, B and $\mathrm{C}$, dimeric monomeric and trimeric hydrolyzable tannins from Cornus officinalis, and orientation of valoneoyl groups in related tannins. Chem. Pharm. Bull. 1989, 37, 2083-2090. [CrossRef] [PubMed]

25. Hatano, T.; Ikegami, Y.; Shingu, T.; Okuda, T. Camptothins A and B, new dimeric hydrolysable tannins from Camptotheca acuminate DECNE. Chem. Pharm. Bull. 1988, 36, 2017-2022. [CrossRef]

26. Okuda, T.; Yoshida, T.; Hatano, T.; Koga, T.; Toh, N.; Kuriyama, K. Circular dichroism of hydrolysable tannins-I ellagitannins and gallotannins. Tetrahedron Lett. 1982, 38, 3937-3940. [CrossRef]

27. Hatano, T.; Hattoir, S.; Okuda, T. Tannins of Coriaria japonica A. GRAY. I. Coriariins A and B, new dimeric and monomeric hydrolyzable tannins. Chem. Pharm. Bull. 1986, 34, 4092-4098. [CrossRef]

28. Alessandra, R.; Venera, C.; Laura, L.; Luca, V.; Angelo, V.; Juan, A.G. Antioxidant activity and antiproliferative action of methanolic extract of Geum quellyon Sweet roots in human tumor cell lines. J. Ethnopharmacol. 2005, 100, 323-332.

29. Rayburn, E.R.; Ezell, S.J.; Zhang, R.W. Anti-inflammatory agents for cancer therapy. Mol. Cell. Pharmacol. 2009, 1, 29-43. [CrossRef] [PubMed]

30. Feelisch, M.; Stamler, J. Methods in Nitric Oxide Research; John Wiley \& Sons: New York, NY, USA, 1996; pp. 492-497.

Sample Availability: Samples of the compounds are available from the authors.

(C) 2016 by the authors; licensee MDPI, Basel, Switzerland. This article is an open access article distributed under the terms and conditions of the Creative Commons by Attribution (CC-BY) license (http://creativecommons.org/licenses/by/4.0/). 